\title{
Anna Wolf Soft Law in EU Migration Cooperation with Associated Countries - A Comparative Perspective
}

\begin{abstract}
The war in Syria transformed the temporary stay of refugees in Turkey, Jordan and Lebanon into a protracted situation. These countries represent strategic partners to the EU in the governance of transit migration. The EU adopted three non-binding bilateral arrangements: The Turkey Statement, the Jordan Compact and the Lebanon Compact. This thesis pursued the following research question: What are the legal effects of the Turkey Statement, the Jordan Compact and the Lebanon Compact on the relations between the EU and these three associated countries in terms of migration and how do they impact the situation of Syrian refugees ${ }^{1}$ hosted in these countries? The Compacts had facilitating and strengthening legal effects on the association links with the EU. In contrast, the Turkey Statement had transformative and multilevel legal effects that contributed to an informalization of relations. This study provided one approach to the lack of legal research on the external dimension of EU governance.
\end{abstract}

Key Words: Soft Law, Migration, EU External Governance, EU Association Law, Turkey Statement

Having graduated at the Institute of European Global Studies in 2019, Anna Wolf completed a 6-month internship at the Mission of Switzerland to the EU in Brussels. She is currently working at the Federal Office of Police (fedpol) as a Specialized Officer in the division for Schengen and EU cooperation.

\footnotetext{
1 The term 'refugee' as used in this thesis describes displaced persons who fled their country of origin due to armed conflict or persecution. UNHCR, “UNHCR Viewpoint: 'Refugee' or 'Migrant' - Which is Right?” 2018, accessed 24 September 2018, https://www.unhcr.org/news/latest/2016/7/55df0e556/unhcr-viewpoint-refugee-migrant-right.html.
} 


\section{Introduction and Research Question}

Since the outbreak of the conflict in 2011, Syria has become the world's largest displacement crisis. ${ }^{2}$ Its neighboring countries host over five million Syrian refugees, with Turkey, Jordan and Lebanon accommodating over 90 percent. $^{3}$ This protracted situation requires new responses. ${ }^{4}$ EU migration cooperation with third countries takes place under the New Partnership Framework (NPF). ${ }^{5}$ The NPF refers to the creation of 'compacts' (comprehensive partnerships) as "key components of the overall relationships between the EU and third countries of origin and transit of migrants." ${ }^{\prime}$ In 2016, the EU adopted three new approaches towards key host and transit countries: the Turkey Statement ${ }^{7}$, the Jordan Compact ${ }^{8}$ and the Lebanon Compact ${ }^{9}$. Both the Turkey Statement and the Jordan Compact are considered an inspiration or a blueprint for arrangements with other third countries. ${ }^{10}$ These instruments embody tendencies towards experimenting with legal frameworks in the EU's external dimension. They may represent a reference point for future EU migration cooperation. Legal research on the external dimension of EU governance is largely missing. Cardwell is among the few researchers working on a legal perspective on this issue. ${ }^{11}$ Similarly, Dawson's work has contributed to the taking up of the concept of governance in legal scholarship on the EU external dimension. ${ }^{12}$ This thesis puts the Turkey Statement, the Jordan Compact and the Lebanon Compact into a comparative perspective as part of an EU governance approach towards the consequences of the war in Syria in associated countries.

2 “Enhancing Resilience and Self-Reliance in Communities. End of Year Report 2017,” UNHCR, 2017, accessed 25 April 2020, https://www.unhcr.org/sy/end-of-year-reports-a-year-in-review, 3.

3 “Syria Regional Refugee Response," UNHCR, accessed 24 September 2018, https://data2.unhcr.org/en/situations/syria.

4 Veronique Barbelet, Jessica Hagen-Zanker, and Dina Mansour-Ille, "The Jordan Compact: Lessons Learnt and Implications for Future Refugee Compacts,” Overseas Development Institute, February 2018, accessed 24 April 2020, https://www. odi.org/sites/odi.org.uk/files/resource-documents/12058.pdf.

5 "Communication from the European Commission on Establishing a New Partnership Framework with Third Countries Under the European Agenda on Migration. COM(2016) 385 final," European Commission, 7 June 2016, accessed 25 April 2020, https://ec.europa.eu/home-affairs/sites/homeaffairs/files/what-we-do/policies/european-agenda-migration/proposalimplementation-package/docs/20160607/communication_external_aspects_eam_towards_new_migration_ompact_en.pdf.

6 European Commission, COM(2016) 385 final, 6.

7 “EU-Turkey Statement. Press Release, 144/16," European Council, 18 March 2016, accessed 25 April 2020, https://www. consilium.europa.eu/en/press/press-releases/2016/03/18/eu-turkey-statement/pdf.

8 Decision No 1/2016 of the EU-Jordan Association Council of 19 December Agreeing on EU-Jordan Partnership Priorities (2016/2388), OJ 2016 L355/31, 2016.

9 Decision No 1/2016 of the EU-Lebanon Association Council of 11 November 2016 Agreeing on EU-Lebanon Partnership Priorities (2016/2368), OJ 2016 L350/114, 2016.

10 European Commission, COM(2016) 385 final, 3; Manuel Schubert and Imke Haase, "How to Combat the Causes of Refugee Flows. The EU-Jordan Compact in Practice," International Reports of the Konrad-Adenauer-Stiftung 34, no. 1 (2018): 103; Arne Niemann and Natascha Zaun, "EU Refugee Policies and Politics in Times of Crisis: Theoretical and Empirical Perspectives," Journal of Common Market Studies 56, no. 1 (January 2018): 9.

11 Paul James Cardwell, "Rethinking Law and New Governance in the European Union: The Case of Migration Management,” European Law Review 41, no. 3 (2016): 363.

12 Mark Dawson, "New Modes of Governance," in A Companion to European Law and International Law, eds. Dennis Patterson and Anna Södersten (Chichester: John Wiley \& Sons, 2016), 119-135. 
The research question reads as follows: What are the legal effects of the Turkey Statement, the Jordan Compact and the Lebanon Compact on the relations between the EU and these three associated countries in the field of migration and how do they impact the situation of Syrian refugees hosted in these countries? For the purpose of this article the second part of the research question is only marginally touched upon in the conclusion.

\section{Methodology}

EU relations with third countries in the field of migration are characterized by a patchwork of instruments: legally binding Association Agreements (AA), Readmission Agreements (RA) and Visa Facilitation Agreements, as well as legally non-binding Mobility Partnerships (MP). ${ }^{13}$ A contextembedded analysis of each soft law instrument is applied to investigate its legal effects. The three instruments are each compared and contrasted with the respective binding agreements (AAs and RAs) as well as non-binding arrangements (Action Plans (AP) and Accession Partnership). The EU's multilevel structure requires an analysis of how they are related to supranational hard law and soft law frameworks.

\section{Theoretical Framework}

\section{The Concept of Governance}

Governance represents a modification or complement of the state government that goes beyond governmental institutions. ${ }^{14}$ Legal scholarship started to incorporate this concept using the notion of 'new modes of governance' (NMG). ${ }^{15}$ NMGs are framed as "an alternative means of delivering EU law and policy". ${ }^{16}$ Hence, NMG are used to reach the same objectives, however, outside the legislative process. EU external governance is conceptualized as taking place "when parts of the acquis communautaire are extended to non-member states." ${ }^{17}$ The field of association

\footnotetext{
13 Sergio Carrera, Raluca Radescu, and Natasja Reslow, "EU External Migration Policies. A Preliminary Mapping of the Instruments, the Actors and their Priorities," Transnational Migration in Transition, (2015): 1-74.

14 Christoph Möllers, "European Governance: Meaning and Value of a Concept," Common Market Law Review 43, no. 2 (2006): 316.

15 See for example: Dawson, "New Modes of Governance"; Anne Peters and Isabella Pagotto, "Soft Law as a New Mode of Governance: A Legal Perspective," Edoc, the Institutional Repository of the University of Basel, 22 September 2016, accessed 25 April 2020, http://edoc.unibas.ch/42734/, 1-35.

16 Dawson, "New Modes of Governance," 120.

17 Sandra Lavenex, "EU External Governance in 'Wider Europe'," Journal of European Public Policy 11, no. 4 (2004): 683.
} 
of neighborhood countries has served as an arena for experimentation with NMGs. ${ }^{18}$

\section{The Concept of Soft Law}

Due to divergent understandings of the relations between law and governance, a clear-cut definition of soft law is missing. Snyder defines soft law as "rules of conduct which, in principle, have no legally binding force but which nevertheless may have practical effects." ${ }^{19}$ This definition was later complemented with "legal effects." ${ }^{20}$

EU hard law is subsumed under the term acquis communautaire. ${ }^{21}$ Whereas regulations and directives are binding acts, recommendations and opinions "shall have no binding force" (Art. 288 TFEU). ${ }^{22}$ Hence, they are the only non-binding instruments recognized in the Treaties. In 2007, the European Parliament (EP) issued a resolution on the use of soft law. ${ }^{23}$ Its understanding of soft law is based on the definition by Senden. ${ }^{24}$ It holds that the purpose of soft law was to "alleviate a lack of formal law-making capacity and/or means of enforcement" ${ }^{25}$ EU case law indicates that soft law is not considered void of any legal effect. In the Grimaldi case, the Court of Justice of the $\mathrm{EU}(\mathrm{CJEU})^{26}$ ruled that "the measures in question cannot be regarded as having no legal effect", meaning that national courts are "bound to take recommendations into consideration". ${ }^{27}$

\section{Legal Effects of Soft Law}

The conceptual framework by Peters and Pagotto is used as a point of departure for the clustering of legal effects. ${ }^{28}$ Soft law can have so-called law-plus effects. It forms the "interpretative context"

18 Stefano Bartolini, “New Modes of European Governance. An Introduction,” in New Modes of Governance in Europe. Governing in the Shadow of Hierarchy, eds. Adrienne Héritie and Martin Rhodes (Basingstoke: Palgrave Macmillan, 2011 ), 15. 19 Francis Snyder, Soft Law and Institutional Practice in the European Community (San Domenico di Fiesole: EUI, 1993 ), 32. 20 Oana Andreea Stefan, "European Union Soft Law: New Developments Concerning the Divide Between Legally Binding Force and Legal Effects,” The Modern Law Review 75, no. 5 (2012): 880.

21 Thomas Oppermann, Dieter Classen, and Martin Nettesheim, Europarecht. Ein Studienbuch (München: C.H.Beck, 2016), 22.

22 Treaty on the Functioning of the European Union, OJ 2016 C 202.

23 "European Parliament Resolution of 4 September 2007 on Institutional and Legal Implications of the Use of 'Soft Law’ Instruments, 2007/2028(INI),” European Parliament, 4 September 2007, accessed 25 April 2020, https://www.europarl. europa.eu/sides/getDoc.do?type=TA\&language=EN\&reference=P6-TA-2007-0366.

24 European Parliament, “European Parliament Resolution of 4 September 2007," see letter K; For the definition see Linda Senden, “Soft Law, Self-Regulation and Co-Regulation in European Law: Where Do They Meet?” Electronic Journal of Comparative Law 9, no. 1 (January 2005): 23.

25 European Parliament, “European Parliament Resolution of 4 September 2007," see letter L.

26 The CJEU consists of two separate courts: The European Court of Justice (ECJ) and the General Court. The CJEU observes the application of the Treaties of the EU and Member States' compliance. In contrast, the ECJ is responsible for preliminary rulings, annulments and appeals (Art. 19 TEU).

27 Judgment of the Court of 13 December 1989, case C-322/88, para. 18.

28 Anne Peters and Isabella Pagotto, "Soft Law as a New Mode of Governance," 22ff. 
for hard law $^{29}$ and serves as an "aid in judicial interpretation". ${ }^{30}$ This is especially relevant for the European Courts since they are obliged to take soft law into consideration. ${ }^{31}$ The legal literature emphasizes that soft law can produce commitment, ${ }^{32}$ also referred to as "de facto persuasiveness". ${ }^{33}$ This effect is particularly strong in long-term relations between the parties. ${ }^{34}$ However, soft law can also have negative legal effects. If it contradicts hard law, soft law may weaken the legitimacy of legal provisions. ${ }^{35}$ This can ultimately undermine existing legal norms and weaken the impact of hard law.

Soft law can have pre-law effects if soft instruments are established where a binding agreement with a third country is absent and not viable. ${ }^{36}$ Thereby, soft law functions as a substitute. In EU migration governance, soft law tools may prepare the ground "for the negotiation and conclusion of future EU readmission agreements. ${ }^{37}$ " One of the dominant legal effects of soft law as a substitute is therefore the precursor effect. ${ }^{38}$

The establishment of soft law facilitates the negotiation of a legally binding agreement. However, the existence of soft law does not always lead to subsequent codification..$^{39}$ If an issue is already governed by soft law, the states may lack incentives to legislate in the same policy area. Soft law can delay or block the creation of legally binding provisions..$^{40}$ This is conceptualized as a pre-empting effect.

29 Bart van Vooren and Ramses A. Wessel, EU External Relations Law. Texts, Cases and Materials (Cambridge: Cambridge University Press, 2014), 53.

30 Snyder, Francis, Soft Law and Institutional Practice in the European Community, 463.

31 C-322/88, para. 18.

32 Vooren and Wessel, EU External Relations Law, 53.

33 Linda Senden, “Soft Post-Legislative Rulemaking: A Time for More Stringent Control," European Law Journal 19, no. 1 (2013): 66

34 Anne Peters and Isabella Pagotto, "Soft Law as a New Mode of Governance," 28.

35 Christine Chinkin, "The Challenge of Soft Law: Development and Change in International Law," International \& Comparative Law Quarterly 38, no. 4 (1989): 866.

36 Paul James Cardwell, “Tackling Europe’s Migration ‘Crisis' Through Law and 'New Governance'," Global Policy 9, no. 1 (2018): 72.

37 "Council Conclusions on the Return and Readmission of Illegally Staying Third-Country Nationals, JAI 554 MIGR 112

COMIX 439," Council of the European Union, 9 June 2016, accessed 25 April 2020, http://data.consilium.europa.eu/doc/document/ST-10020-2016-INIT/en/pdf, 4.

38 Daniel Thym, “Towards International Migration Governance? The European Contribution," in The EU's Role in Global Governance: The Legal Dimension, eds. Bart van Vooren, Steven Blockmans, and Jan Wouters (Oxford: Oxford University Press, 2013), 300; Anne Peters and Isabella Pagotto, "Soft Law as a New Mode of Governance," 22.

39 Thomas Gammeltoft-Hansen et al., "What is a Compact? Migrants' Rights and State Responsibilities Regarding the Design of the UN Global Compact for Safe, Orderly and Regular Migration," Raoul Wallenberg Institute of Human Rights and Humanitarian Law, 2017, accessed 25 April 2020, https://rwi.lu.se/app/uploads/2017/10/RWI_What-is-a-compact-test_101017senaste-1.pdf, 10.

40 Ibid. 
Soft law is often experimental in design and may entail creative, new approaches. ${ }^{41}$ It can be consulted during the creation of hard law. Thym also considers soft law instruments as a "laboratory for cooperation". ${ }^{42}$

Multilevel effects are distinctive to the EU's governance structure. Soft law created at the supranational level can have effects at the national governance level of either the Member States or associated third countries. EU soft law can impact the Member States ${ }^{\prime 43}$ and possibly also the associated countries' legal practice.

For the purpose of this thesis, soft law is understood as a legally non-binding mode of governance that is used to induce a particular behavior in the associated third country and can produce legal effects.

\section{The Association Process}

Based on Article 217 TFEU, "the Union may conclude with one or more third countries or international organizations agreements establishing an association involving reciprocal rights and obligations, common action and special procedure." In the Demirel case, the CJEU specified the significance of AAs as "creating special, privileged links with a non-member country which must, at least to a certain extent, take part in the Community system." ${ }^{44}$ AA provisions are often worded similarly or identically to EU law. ${ }^{45}$ The legal literature refers to this privileged relationship as "integration without membership", because the third country becomes involved with the "EU legal space" ${ }^{46}$ The European Court of Justice (ECJ) concluded in the seminal Haegeman case that it was entitled to give preliminary rulings on the interpretation of AA provisions. ${ }^{47} \mathrm{EU}$ law includes the so-called association acquis (comprised of the AA, any court judgments on the AA, Additional Protocols and Decisions of the AC). ${ }^{48}$ Member States are bound by AAs based on EU law. ${ }^{49}$

41 Charles F. Sabel and Jonathan Zeitlin, "Learning From Difference: The New Architecture of Experimentalist Governance in the EU," in Experimentalist Governance in the European Union. Towards a New Architecture, ed. Charles F. Sabel and Jonathan Zeitlin (Oxford: Oxford University Press, 2010), 1.

42 Thym, "Towards International Migration Governance," 294.

43 Senden, "Soft Post-Legislative Rulemaking," 66.

44 C-12/86, Demirel v Stadt Schwäbisch Gmünd, ECLI:EU:C:1987:232, para. 9.

45 Christa Tobler, "Context-related Interpretation of Association Agreements. The Polydor Principle in a Comparative Perspective: EEA Law, Ankara Association Law and Market Access Agreements between Switzerland and the EU," in Rights of Third-Country Nationals under EU Association Agreements, ed. Daniel Thym and Margarite Zoeteweij-Turhan (Leiden: Brill Nijhoff, 2015), 101.

46 Vooren and Wessel, EU External Relations Law, 64.

47 C-181/73, Haegeman v Belgium, ECLI:EU:C:1974:41, para. 5-6.

48 Daniel Thym, "Constitutional Foundations of the Judgements on the EEC-Turkey Association Agreement," in Rights of Third-Country Nationals under EU Association Agreements, eds. Daniel Thym and Margarite Zoeteweij-Turhan (Leiden: Brill Nijhoff, 2015), 13.

49 Vooren and Wessel, EU External Relations Law, 42. 
In association relations, an Accession Partnership is established with potential candidates for accession, a non-binding political agreement building on the AA. ${ }^{50}$ It determines in detail the issues to be discussed during the pre-accession process. ${ }^{51}$ Accordingly, the EU agrees upon a non-binding Action Plan (AP) with other associated countries..$^{52}$ APs represent the main soft law instruments guiding the association relations with Jordan and Lebanon. The Accession Partnership represents the equivalent for Turkey.

\section{Overview of the Bilateral Relations with Turkey, Jordan and Lebanon}

The EU and Turkey have pursued a pre-accession strategy for decades. Since 2005, accession negotiations are ongoing. In contrast, the relations with Jordan and Lebanon take place under the European Neighborhood Policy (ENP) and further evolved through APs and Association Council (AC) Decisions. Turkey is a signatory to the Geneva Convention ${ }^{53}$ without the 1967 Protocol. Neither Jordan nor Lebanon has signed the Geneva Convention. ${ }^{54}$

\section{EU-Turkey Cooperation on Migration}

The EU and Turkey concluded an RA in 2014, which regulated the modalities of irregular transit migration through Turkey. ${ }^{55}$ The RA was preceded by the 2002 bilateral RA between Turkey and Greece. ${ }^{56}$ In June 2018, the Turkish Foreign Minister announced the unilateral suspension of the RA with Greece. ${ }^{57}$ On 18 March 2016, the Council of the EU published the Turkey Statement in

50 Elsa Tulmets, "Experimentalist Governance in EU External Relations: Enlargement and the European Neighbourhood Policy," in Experimentalist Governance in the European Union. Towards a New Architecture, eds. Charles F. Sabel and Jonathan Zeitlin (Oxford: Oxford University Press, 2010), 308.

51 Council Decision of 18 February 2008 on the Principles, Priorities and Conditions Contained in the Accession Partnership with the Republic of Turkey and Repealing Decision 2006/35/EC, OJ 2008 L51/4, 2008, Rec. 1.

52 European Commission, "Wider Europe - Neighbourhood: A New Framework for Relations with our Eastern and Southern Neighbours,” COM(2003) 104 final, 2003, accessed 25 April 2020, https://www.europarl.europa.eu/sides/getDoc. do?pubRef=-//EP//NONSGML+REPORT+A5-2003-0378+0+DOC+PDF+V0//EN, 16.

53 "Convention and Protocol Relating to the Status of Refugees," United Nations General Assembly, Geneva 28 July 1951, United Nations, Treaty Series, vol. 189, 1951.

54 Ibid.

55 Agreement between the European Union and the Republic of Turkey on the Readmission of Persons Residing without Authorisation, OJ 2014 L 134/3, 2014.

56 Sarah Wolff, "The Politics of Negotiating EU Readmission Agreements: Insights from Morocco and Turkey," European Journal of Migration and Law 16, no. 1 (2014): 90.

57 Ali Kucukgocmen and Karolina Tagaris, “Turkey Suspends Migrant Readmission Deal with Greece: Anadolu,” Reuters, 7 June 2018, accessed 8 November 2018, https://www.reuters.com/article/us-turkey-security-greece/turkey-suspends-migrantreadmission-deal-with-greece-hurriyet-idUSKCN1J31OO. 
a press release. ${ }^{58}$ From 20 March 2016 onwards, all irregular migrants arriving from Turkey to Greek islands were to be returned to Turkey. ${ }^{59}$ For every returned Syrian, another Syrian would be resettled from Turkey to the EU (para. 2). ${ }^{60}$ The Statement promised to accelerate the implementation of the EU-Turkey Visa Liberalization Roadmap and the resumption of accession negotiation chapters. ${ }^{61}$

\section{EU-Jordan Cooperation on Migration}

Migration is exclusively regulated through soft law in EU-Jordan relations. The main objective of the MP from 2014 was the simultaneous negotiation of a binding RA together with a visa facilitation agreement. ${ }^{62}$ In December 2016, the Jordan Compact was adopted. ${ }^{63}$ It set quantifiable goals: Jordan committed to create up to 100,000 jobs for Syrian refugees. ${ }^{64}$ The EU pledged to provide financial assistance and simplify Rules of Origin requirements for products from 18 Special Economic Zones for a period of ten years. ${ }^{65}$ The AC decided that the Jordan Compact replaced the 2012 AP. $^{66}$

\section{EU-Lebanon Cooperation on Migration}

Migration in the EU-Lebanon cooperation is exclusively regulated through soft law. The 2013 AP restated the goal of negotiating an RA. ${ }^{67}$ Up until now, neither an RA nor an MP has been adopted. In November 2016, the AC adopted the Lebanon Compact. ${ }^{68}$ Lebanon committed to simplifying domestic regulations of labor market access for Syrian refugees. ${ }^{69}$ The EU committed to job creation for young Lebanese and Syrians, including through new Technical Vocational Education and Training (TVET) programs. ${ }^{70}$

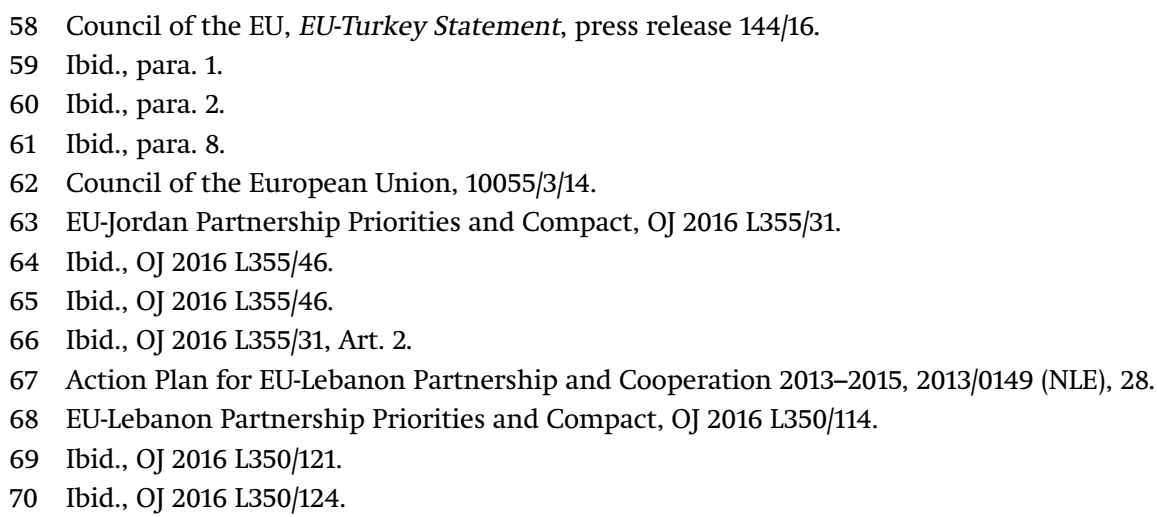




\section{The Legal Effects of the Soft Law Instruments}

\section{Association Relations}

The Jordan Compact and the Lebanon Compact were adopted by decision of the respective AC. Art. 217 in conjunction with Art. 218(9) TFEU formed the legal basis. ${ }^{71}$ Hence, they were closely integrated into the association process. Although the Turkey Statement's provisions were linked to aspects of the accession relations, it was adopted outside of the legal association framework. The General Court ruled that the Turkey Statement was not concluded under Art. 218 TFEU. ${ }^{72}$ The Compacts' main legal effect was facilitating the achievement of the goals set out in the AA. This corresponds to Cardwell's concept of soft law coexisting with hard law by forming part of an established legal framework. ${ }^{73}$ The Compacts operated within the legal space of the AA. The Statement did not advance the accession negotiations.

With the Compacts, migration continues to be governed exclusively by soft law. In contrast to the preceding APs, the Compacts interlink different policies as a tailor-made response to the consequences of the war in Syria. This interconnection is especially pronounced in the Jordan Compact, where the relaxation of Rules of Origin was directly tied to a minimum quota of refugee labor. ${ }^{74}$ The NPF conceptualized Compacts as embedded in existing partnerships. ${ }^{75}$ The EU made use of its association relations with Jordan and Lebanon to implement specific soft law on migration.

\section{Migration Arrangements}

The Turkey Statement addressed amongst other aspects the readmission of third-country nationals, which had already been regulated in the EU-Turkey RA. The Turkey Statement is thus not a precursor to hard law. A limited assessment of law implementation showed that neither the Greece-Turkey RA nor the third-country national clause of the EU-Turkey RA was effectively applied. Current EU documentation has revealed that the Turkey Statement in effect covered for returns itself. Binding law did not achieve the objective of readmission between Turkey and Greece. Thus, a non-binding arrangement with the same goal was adopted. This corresponds to the concept of NMGs as "regulatory alternatives" extra-legal way. This finding is relevant as it shows how the procedural safeguards defined in Art. 218 TFEU were circumvented. Given that the Turkey Statement currently covers the largest

71 European Commission, JOIN(2018) 35 final, 2018/0406 (NLE), 3.

72 T-192/16, NF v European Council, para. 70.

73 Cardwell, “Tackling Europe's Migration 'Crisis' Through Law and 'New Governance”, 72.

74 EU-Jordan Partnership Priorities and Compact, OJ 2016 L355/31.

75 European Commission, COM(2016) 385 final, 5.

76 Anne Peters and Isabella Pagotto, "Soft Law as a New Mode of Governance," 15. 
migration movements between Turkey and EU territory, this could further delay the application of the binding third-national clause of the EU-Turkey RA, as the EU, the Member States and Turkey might lack incentives to advance its effective application. Soft law can have a de-legitimizing and weakening effect if coexisting with hard law. Also, it can have a pre-empting effect if binding regulation is lacking. The results showed how these two theoretical dimensions could be valuably brought together to apply to the field of law implementation. If a binding regulation exists but is not applied in practice, soft law might not replace it legally, but rather substitutes its practical function. In turn, this might block the full implementation of the binding rule.

Obligations under the Turkey Statement went further than under the EU-Turkey RA. The Statement expanded the readmission scheme to persons arriving irregularly from Turkey to Greece in search of international protection. The Statement as an informal RA currently represents the only basis upon which Syrian refugees can be returned from Greece to Turkey. The dimension of this effect is not limited to the relations between the Member States and Turkey. Readmission under the EU-Turkey RA was not based on the concept of 'safe third country'. ${ }^{77}$ In contrast, the Statement stipulated the return of irregular migrants including those seeking international protection. Hence, the Statement transformed Turkey's legal status. In a broader sense, one has to question what this means for the scope of Art. 38(1) APD. The 'safe third country' concept provides for the return of persons seeking international protection in the EU to a third country, if protection is in line with the Geneva Convention and the 1967 Protocol. ${ }^{78}$ Turkey upheld the geographical limitation to the Convention, which raises doubts regarding protection levels. The fact that Turkey became considered a 'safe third country' by means of an informal arrangement weakened this legal concept. In future migration cooperation, this might lead to a more yielding application of the 'safe third country' concept. The legal effects of the Statement go beyond bilateral relations and might change EU legal practice regarding a key concept of its readmission policy.

The concept of EU external governance is understood as extending parts of the acquis to third countries. ${ }^{79}$ However, theory does not account for the reverse process. The Turkey Statement showed that soft law can weaken a supranational legal concept. In a broader sense, this finding illustrates how hard law and soft law as a means of governance mutually interact, not only complementing but also transforming each other.

77 Within the meaning of Art. 38(1) Asylum Procedure Directive, OJ 2013 L180/60.

78 Art. 38(1) Asylum Procedure Directive, OJ 2013 L180/60.

79 Lavenex, "EU External Governance in 'Wider Europe'," 683. 


\section{EU Measures}

The Jordan and the Lebanon Compact transformed the EU governance approach to migration in third countries. The negotiation of a binding RA represented a priority on the association agenda with both countries. The EU-Lebanon AA provided a readmission clause that was found to not be directly applicable, as the implementation of a readmission scheme would require the adoption of an RA..$^{80}$ Interestingly, the Jordan and the Lebanon Compact not only omit the negotiation of an RA, they also lack an informal readmission arrangement. This finding illustrates how the Compacts reorient the EU's governance of migration in its relations with third countries. In line with the $\mathrm{NPF}^{81}$, the new focus lies on support for the integration of Syrian refugees close to their origin. The Jordan and the Lebanon Compact were the first compacts concluded under the NPF. They will potentially inspire future compacts with third countries.

In contrast, the Turkey Statement had an inspirational effect at the level of binding supranational law. Elements of the Turkey Statement are about to become codified into the acquis. In particular, the expedited procedure of the Turkey Statement was integrated into a legislative proposal for a new EU regulation on resettlement. ${ }^{82}$ The expedited procedure entails that rapid resettlement could be conducted without assessing refugee status, only evaluating the eligibility for subsidiary protection. ${ }^{83}$ Further, the Statement prioritizes migrants for resettlement who have not previously entered or tried to enter the EU irregularly. ${ }^{84}$ The Commission's legislative proposal transformed this provision into a condition for non-eligibility, explicitly excluding these persons from resettlement. ${ }^{85}$ If this proposal were adopted, existing vulnerability criteria for resettlement would be complemented with a questionable condition on previous migration behavior originating in the Turkey Statement. This finding reveals the reach of the legal effects of a soft law instrument that was adopted outside of formal association relations.

\section{The Legal Effects on the Relations with Turkey, Jordan and Lebanon}

Despite the high level of legal integration between the EU and Turkey, the Member States and Turkey resorted to soft law outside of the EU institutional framework. This was justified as an emergency measure. However, the Statement's legal effects considerably exceeded bilateral

80 This condition was established by CJEU practice. Oppermann, Classen, and Nettesheim, Europarecht, 667.

81 European Commission, COM(2016) 385 final, 4.

82 European Commission, Proposal for a Regulation - Establishing a Union Resettlement Framework and amending Regulation (EU) No 516/2014 of the European Parliament and the Council, COM(2016) 468 final, 2016, 2.

83 Ibid., 13.

84 EU-Turkey Statement, para. 2.

85 European Commission, $\operatorname{COM}(2016) 468$ final, 12. 
relations and were found to contradict its original purpose of an emergency measure.

The Compacts' main legal effect was facilitating the implementation of the AAs. The Jordan Compact in particular deepened association relations by increasing Jordan's participation in the EU trade regime. In contrast, the Turkey Statement substituted binding readmission provisions in practice, had a transformative effect on the EU 'safe third country' concept and an inspirational effect on proposed EU secondary legislation. The Statements' provisions did not advance accession negotiations. Ott's multilayer framework proves useful in explaining this finding. ${ }^{86}$ The informalization of the readmission scheme advances EU-Turkey relations in the third legal layer, however, not in the second layer of accession. The relations thus rather develop towards a 'privileged partnership' than towards membership. The Turkey Statement had multilevel legal effects reaching beyond the bilateral relations, whereas the effects of the Compacts were limited to the respective association relations.

Institutional factors explain this finding to some extent. Decisions adopted by the AC are bound by the AA, which in turn is based on Art. 217 TFEU. This limited the Compacts to conforming to this institutional setting. The adoption of the Turkey Statement outside an institutionalized framework allowed integrating provisions not necessarily in line with the AA and the acquis, which ultimately produced more far-reaching legal effects. The insights from the case-based approach pursued in this thesis developed the new hypothesis that soft law adopted outside of the association relations rather produces transformative and multilevel legal effects, whereas soft law adopted within the association relations generates law-plus effects.

\section{Conclusion}

The conceptual lens of soft law as a means of governance applied in this thesis allowed a new perspective on recent EU migration cooperation with associated countries. The Jordan and the Lebanon Compact were found to mainly have law-plus effects. They facilitated the implementation of the AA provisions. In contrast, the Turkey Statement was adopted outside of the accession relations and steered EU-Turkey relations towards an informal partnership. Beyond that, it had far-reaching inspiration and transformation effects at the supranational level. Most importantly,

86 Andrea Ott, “EU-Turkey Cooperation in Migration Matters: a Game Changer in a Multi-layered Relationship?” Centre for the Law of EU External Relations, 2017, accessed 15 September 2018, https://papers.ssrn.com/sol3/papers.cfm?abstract_ id=3118921. 
it changed Turkey's status to a 'safe third country'. At the individual level, the instruments impacted refugees' migration patterns, their livelihood and the precariousness of their stay in the host country. The adherence to the legally non-binding commitments means that all three arrangements produced 'de facto persuasiveness'. The insights resulted in a new hypothesis: soft law adopted outside of the institutional setting of association relations has the potential to generate multilevel transformation effects, whereas soft law adopted within association relations rather produces law-plus effects.

This thesis situates itself in research on EU external governance. Legal scholarship uses the concept of governance to analyze the interactions between binding and non-binding arrangements. However, a legal perspective on the external dimension of EU governance is missing. Leading legal scholars engaging with governance primarily focus on the internal dimension. This thesis tied in with Cardwell's argument that the concept of governance might provide a useful tool for analyzing EU relations with third countries. It contributed new insights of how soft law interacts with hard law within the setting of association relations. Apart from soft law's facilitating effects on hard law, also mutually transforming processes were identified.

Further, this thesis illustrated that soft law has far-reaching impacts on refugees residing in host countries and sometimes - in line with Cardwell - these effects are even stronger than the effects of hard law. The design and adoption of soft law instruments therefore requires a careful and critical evaluation of the effects at the individual level as well as a localized understanding of refugee protection in host countries.

Migration will remain high on the EU's agenda, and related challenges in external relations are increasingly met with soft law approaches. Hence, further research on the legal dimension of EU external governance is necessary to advance the understanding of how soft law interacts with hard law and whether this in fact embodies - as argued by Dawson and Cardwell - a new paradigm beyond the prevalent idea of 'integration through law'. 


\section{Bibliography}

\section{Primary Law}

Treaty on European Union, OJ 2016 C 202.

Treaty on the Functioning of the European Union, OJ 2016 C 202.

United Nations General Assembly. "Convention and Protocol Relating to the Status of Refugees."

Geneva 28 July 1951, United Nations, Treaty Series, vol. 189, 1951.

\section{Secondary Measures}

\section{Secondary Law}

Agreement between the European Union and the Republic of Turkey on the Readmission of Persons Residing without Authorisation, OJ 2014 L 134/3, 2014.

Directive 2013/32/EU on common procedures for granting and withdrawing international protection, OJ 2013 L180/60.

\section{Soft Law}

Council Decision of 18 February 2008 on the principles, priorities and conditions contained in the Accession Partnership with the Republic of Turkey and repealing Decision 2006/35/EC, OJ 2008 L51/4.

Council of the European Union. "EU-Turkey Statement", press release 144/16, 2016, accessed on 29 April 2020. https://www.consilium.europa.eu/en/press/press-releases/2016/03/18/ eu-turkey-statement/pdf.

Council of the European Union. "Joint Declaration establishing a Mobility Partnership between the Hashemite Kingdom of Jordan and the European Union and its participating Member States." 2014, 10055/3/14.

Decision No 1/2016 of the EU-Jordan Association Council of 19 December agreeing on EU-Jordan Partnership Priorities (2016/2388), OJ 2016 L355/31.

Decision No 1/2016 of the EU-Lebanon Association Council of 11 November 2016 agreeing on EULebanon Partnership Priorities (2016/2368), OJ 2016 L350/114.

EU-Jordan Association Council. “EU-Jordan Action Plan.” 2016, UE-RHJ 3301/05.

EU-Jordan Association Council. “European Neighbourhood Action Plan.” 2012, UE-RHJ 3302/12.

EU-Lebanon Association Council. "Action Plan for EU-Lebanon Partnership and Cooperation 2013-2015." 2013, 2013/0149 (NLE).

\section{Judgements of the CJEU}

Order of the General Court of 28 February 2017, T-192/16, NF v European Council, ECLI:EU:T:2017:128. Judgement of the Court of 13 December 1989, C-322/88, Grimaldi v Fonds des maladies professionelles, ECLI:EU:C:1989:646. 
Judgement of the Court of 30 September 1987, C-12/86, Demirel v Stadt Schwäbisch Gmünd, ECLI:EU:C:1987:232.

Judgement of the Court of 30 April 1974, C-181/73, Haegeman v Belgium, ECLI:EU:C:1974:41.

\section{Other Official Documentation}

Council of the European Union. "Council conclusions on the return and readmission of illegally staying third-country nationals.” JAI 554 MIGR 112 COMIX 439, 9 June 2016, accessed 25 April 2020. http://data.consilium.europa.eu/doc/document/ST-10020-2016-INIT/en/pdf.

European Commission. "Joint Proposal for a Council Decision - as regards the two-year extension of EU-Jordan Partnership Priorities.” 2018, JOIN(2018) 35 final, 2018/0406 (NLE).

European Commission. "Proposal for a Regulation - establishing a Union Resettlement Framework and amending Regulation (EU) No 516/2014 of the European Parliament and the Council." 2016, $\operatorname{COM}(2016) 468$ final.

European Commission. "Communication from the Commission - on establishing a new Partnership Framework with third countries under the European Agenda on Migration." 2016, $\operatorname{COM}(2016) 385$ final.

European Commission. "Wider Europe - Neighbourhood: A New Framework for Relations with our Eastern and Southern Neighbours." 2003, COM(2003) 104 final.

European Parliament. "European Parliament Resolution of 4 September 2007 on Institutional and Legal Implications of the Use of 'Soft Law' Instruments, 2007/2028(INI)." 4 September 2007, accessed 25 April 2020. https://www.europarl.europa.eu/sides/getDoc. do?type $=$ TA\&language $=$ EN\&reference $=P 6-T A-2007-0366$.

\section{Online Publications}

UNHCR. “Syria Regional Refugee Response.” 2018, accessed 24 September 2018. https://data2.unhcr.org/en/situations/syria.

UNHCR. "Enhancing Resilience and Self-Reliance in Communities. End of Year Report 2017.” 2017, accessed 25 April 2020. https://www.unhcr.org/sy/end-of-year-reports-a-year-in-review.

UNHCR. “UNHCR Viewpoint: 'Refugee' or 'Migrant' - Which is Right?” 2016, accessed 24 September 2018. https://www.unhcr.org/news/latest/2016/7/55df0e556/unhcr-viewpoint-refugee-migrant-right.html. 


\section{Literature}

Barbelet, Veronique, Jessica Hagen-Zanker, and Dina Mansour-Ille. "The Jordan Compact: Lessons Learnt and Implications for Future Refugee Compacts." Overseas Development Institute, February 2018, accessed 24 April 2020: 1-8. https://www.odi.org/sites/odi.org.uk/files/resource-documents/12058.pdf.

Bartolini, Stefano. "New Modes of European Governance. An Introduction.” In New Modes of Governance in Europe. Governing in the Shadow of Hierarchy, edited by Adrienne Héritie and Martin Rhodes, 1-18. Basingstoke: Palgrave Macmillan, 2011.

Cardwell, Paul James. “Tackling Europe’s Migration 'Crisis' Through Law and 'New Governance'.” Global Policy 9, no. 1 (2018): 67-75.

Cardwell, Paul James. "Rethinking Law and New Governance in the European Union: The Case of Migration Management.” European Law Review 41, no. 3 (2016): 362-378.

Carrera, Sergio, Raluca Radescu, and Natasja Reslow. "EU External Migration Policies - A Preliminary Mapping of the Instruments, the Actors and their Priorities." Project report prepared for the FP7 project 'Transnational Migration in Transition: Transformative Characteristics of Temporary Mobility of People' (EURA-NET). 2015, 1-74.

Chinkin, Christine. "The Challenge of Soft Law: Development and Change in International Law." International \& Comparative Law Quarterly 38, no. 4 (1989): 850-866.

Dawson, Mark. "New Modes of Governance." In A Companion to European Law and International Law, edited by Dennis Patterson and Anna Södersten, 119-135. Chichester: John Wiley \& Sons, 2016.

Gammeltoft-Hansen, Thomas et al. “What is a Compact? Migrants' Rights and State Responsibilities Regarding the Design of the UN Global Compact for Safe, Orderly and Regular Migration." Raoul Wallenberg Institute of Human Rights and Humanitarian Law, 2017, accessed 25 April 2020. https://rwi.lu.se/app/uploads/2017/10/RWI_What-is-a-compact-test_101017-senaste-1.pdf.

Kucukgocmen, Ali, and Karolina Tagaris. "Turkey Suspends Migrant Readmission Deal with Greece: Anadolu.” Reuters, 7 June 2018, accessed 8 November 2018. https://www.reuters.com/ article/us-turkey-security-greece/turkey-suspends-migrant-readmission-deal-with-greece-hurriyet-idUSKCN1J310O.

Lavenex, Sandra. “EU External Governance in 'Wider Europe'." Journal of European Public Policy 11, no. 4 (2004): 680-700.

Möllers, Christoph. "European Governance: Meaning and Value of a Concept." Common Market Law Review 43, no. 2 (2006): 313-336.

Niemann, Arne, and Natascha Zaun. "EU Refugee Policies and Politics in Times of Crisis: Theoretical and Empirical Perspectives.” Journal of Common Market Studies 56, no. 1 (January 2018): 3-22. 
Oppermann, Thomas, Dieter Classen, and Martin Nettesheim. Europarecht. Ein Studienbuch. München: C.H.Beck, 2016.

Ott, Andrea. "EU-Turkey Cooperation in Migration Matters: a Game Changer in a Multi-layered Relationship?" Centre for the Law of EU External Relations, 2017, accessed 15 September 2018. https://papers.ssrn.com/sol3/papers.cfm?abstract_id=3118921.

Peters, Anne, and Isabella Pagotto. “Soft Law as a New Mode of Governance: A Legal Perspective.” Edoc, the Institutional Repository of the University of Basel, 22 September 2016, accessed 25 April 2020. http://edoc.unibas.ch/42734/. 1-35.

Sabel, Charles F., and Jonathan Zeitlin. "Learning From Difference: The New Architecture of Experimentalist Governance in the EU." In Experimentalist Governance in the European Union. Towards a New Architecture, edited by Charles F. Sabel and Jonathan Zeitlin, 1-28. Oxford: Oxford University Press, 2010.

Schubert, Manuel, and Imke Haase. "How to Combat the Causes of Refugee Flows. The EU-Jordan Compact in Practice." International Reports of the Konrad-Adenauer-Stiftung 34, no. 1 (2018): 92-105.

Senden, Linda. “Soft Post-Legislative Rulemaking: A Time for More Stringent Control.” European Law Journal 19, no. 1 (2013): 57-75.

Senden, Linda. "Soft Law, Self-Regulation and Co-Regulation in European Law: Where Do They Meet?" Electronic Journal of Comparative Law 9, no. 1 (January 2005): 1-27.

Snyder, Francis. Soft Law and Institutional Practice in the European Community. San Domenico di Fiesole: EUI, 1993.

Stefan, Oana Andreea. "European Union Soft Law: New Developments Concerning the Divide Between Legally Binding Force and Legal Effects." The Modern Law Review 75, no. 5 (2012): 879-893.

Thym, Daniel. "Constitutional Foundations of the Judgements on the EEC-Turkey Association Agreement." In Rights of Third-Country Nationals under EU Association Agreements, edited by Daniel Thym and Margarite Zoeteweij-Turhan, 11-38. Leiden: Brill Nijhoff, 2015.

Thym, Daniel. “Towards International Migration Governance? The European Contribution.” In The EU's Role in Global Governance: The Legal Dimension, edited by Bart van Vooren, Steven Blockmans, and Jan Wouters, 289-305. Oxford: Oxford University Press, 2013.

Tobler, Christa. "Context-related Interpretation of Association Agreements. The Polydor Principle in a Comparative Perspective: EEA Law, Ankara Association Law and Market Access Agreements between Switzerland and the EU.” In Rights of Third-Country Nationals under EU Association Agreements, edited by Daniel Thym and Margarite Zoeteweij-Turhan, 101126. Leiden: Brill Nijhoff, 2015. 
Tulmets, Elsa. "Experimentalist Governance in EU External Relations: Enlargement and the European Neighbourhood Policy." In Experimentalist Governance in the European Union. Towards a New Architecture, edited by Charles F. Sabel and Jonathan Zeitlin. 297-324. Oxford: Oxford University Press, 2010.

Vooren, Bart van, and Ramses A. Wessel. EU External Relations Law. Texts, Cases and Materials. Cambridge: Cambridge University Press, 2014.

Wolff, Sarah. "The Politics of Negotiating EU Readmission Agreements: Insights from Morocco and Turkey." European Journal of Migration and Law 16, no. 1 (2014): 69-95. 